\title{
Assessment of Potential Prognostic Value of Peroxiredoxin I in Oral Squamous Cell Carcinoma [Corrigendum]
}

Shen Y, Xu H, Li L, et al. Cancer Manag Res. The correct Figure 7 is shown below.

2021;13:5725-5737.

The authors have advised due to an error at the time of figure assembly, the legend shown in Figure 7D was incorrectly written as AUC at 1 years, AUC at 2 years and AUC at 3 years, it should read AUC at 1 years, AUC at 3 years and AUC at 5 years, respectively.
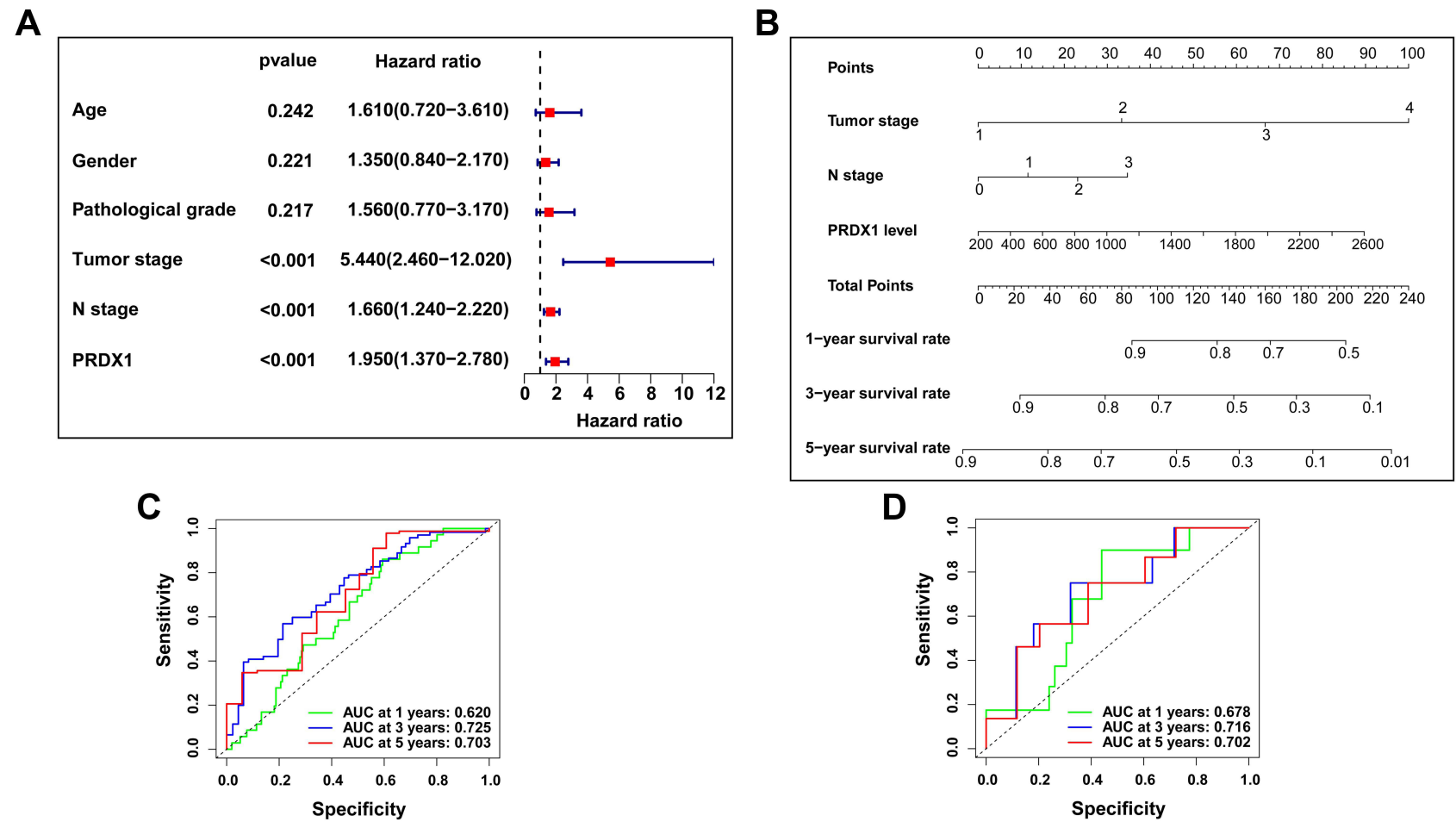

The authors apologize for this error and advise it does not affect the scientific conclusions of the paper.

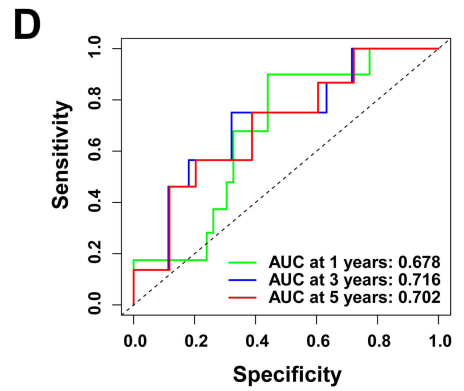

Figure 7 The establishment of a nomogram that can predict the 1-, 3-, and 5-year survival rates of patients with OSCC. (A) Cox proportional hazards regression analysis for PRDXI and clinical features; (B) A nomogram containing Tumor stage, N stage and PRDXI level; (C and D) The accuracy of nomogram in the TCGA cohort and testing cohort was verified by the ROC curve.

\section{Publish your work in this journal}

Cancer Management and Research is an international, peer-reviewed open access journal focusing on cancer research and the optimal use of preventative and integrated treatment interventions to achieve improved outcomes, enhanced survival and quality of life for the cancer patient.
The manuscript management system is completely online and includes a very quick and fair peer-review system, which is all easy to use. Visit http://www.dovepress.com/testimonials.php to read real quotes from published authors. 